\title{
Análise do grau global e tensão da voz em cantores de roque $e^{* * * *}$
}

\author{
Overall voice and strain level analysis in rock singers
}

\begin{abstract}
Aline Gonsalves*
Elisabeth Amin**

Mara Behlau***
\end{abstract}

*Fonoaudióloga. Especialista em Voz com Curso no Centro de Estudos da Voz (CEV). Pesquisadora Associada ao CEV. Endereço para correspondência: R. Praia de Barra Grande, Quadra 12 Lote 17 - Lauro de Freitas - BA CEP 42700-000

(alinegonsalves@bol.com.br)

**Fonoaudióloga. Especialista em Voz pelo Conselho Federal de

Fonoaudiologia (CFFa). Professora do CEV. Orientadora de Técnica Vocal do Coral da Universidade de São Paulo (USP).

***Fonoaudióloga. Doutora em Distúrbios da Comunicação Humana pela Universidade Federal de São Paulo (Unifesp). Professora do Curso de Especialização do CEV.

****Trabalho Realizado no CEV como monografia para a Conclusão do Curso de Especialização em Voz.

Artigo Original de Pesquisa

Artigo Submetido a Avaliação por Pares

Conflito de Interesse: não

Recebido em 17.03.2010.

Revisado em 04.08.2010.

Aceito para Publicação em 01.09.2010.

\begin{abstract}
Background: overall voice and strain level analysis in rock singers. Aim: to analyze the voice o rock singers according to two specific parameters: overall level of vocal deviation (OLVD) and strain level (SL); to compare these parameters in three different music samples. Method: participants were 26 male rock singers, ranging in age from 17 to 46 years (mean = 29.8 years). All of the participants answered a questionnaire for sample characterization and were submitted to the recording of three voice samples: Brazilian National Anthem (BNA), Satisfaction and self-selected repertoire song (RS). Voice samples were analyzed by five speech-language pathologists according to OLVD and SL. Statistical analysis was done using the software SPSS, version 13.0. Results: statistically significant differences were observed for the mean values of OLVD and SL during the performance of Satisfaction (OLVD = 32.8 and SL $=0.024$ $/ p=0.024)$ and during the RS performance $(O L V D=38.4$ and $S L=55.8 / p=0.010)$. The values of OLVD and SL are directly proportional to the samples of the BNA* and RS**, i.e. the higher the strain the higher the OLVD (p,0.001*; $\left.\mathrm{p}=0.010^{* *}\right)$. When individually analyzing the three song samples, it is observed that the OLVD does not vary significantly among them. However, the mean values present a trend to increase from non-rock to rock performances (24.0 BNA / 32.8 Satisfaction / 38.4 RS). The level of strain found during the BNA performance presents statistically significant difference when compared to the rock performances (Satisfaction and RS, $\mathrm{p}=0.008$ and $\mathrm{p}=0.001$ ). Conclusion: the obtained data suggest that rock style is related to the greater use of vocal strain and that this strain does not necessarily impose a negative impression to the voice, but corresponds to a common interpretative factor related to this style of music.
\end{abstract}

Key Words: Voice; Music; Voice Quality.

\section{Resumo}

Tema: análise do grau global e tensão na voz de cantores de roque. Objetivo: analisar a voz de cantores de roque em dois parâmetros específicos: grau global de desvio vocal (GGDV) e grau de tensão(GT), comparando esses parâmetros em três trechos de músicas. Métodos: participaram 26 cantores de roque com idade entre 17 e 46 anos (média = 29:08 anos). Todos responderam a um questionário para caracterização da amostra e realizaram a gravação dos trechos selecionados: Hino Nacional Brasileiro (HNB), Satisfaction e música do repertório auto-selecionada (MR). As amostras foram avaliadas por cinco fonoaudiólogas nos parâmetros GGDV e GT. A análise estatística foi realizada pelo programa SPSS versão 13.0. Resultados: foram encontradas diferenças estatisticamente significantes para os valores médios de GGDV e GT na música Satisfaction $(\mathrm{GGDV}=32,8$ e GT = 45,8 / p = 0,024) e na MR (GGDV = 38,4 e GT = 55,8 / p = 0,010). Os valores de GGDV e GT possuem relação diretamente proporcional nos trechos HNB* e MR**, sendo que quanto maior a tensão maior o GGDV ( $\left.\mathrm{p}=<0,001^{*}, \mathrm{p}=0,010^{* *}\right)$. Quando se analisa individualmente os três trechos, encontra-se que o GGDV não varia de forma significante para as músicas, porém seus valores médios apresentam uma tendência crescente do não roque para o roque (24,0 HNB / 32,8 Satisfaction / 38,4 MR), porém a tensão encontrada no HNB apresenta diferença estatisticamente significante da tensão encontrada nas músicas de roque (Satisfaction e MR, p = 0,008 e p =0,001). Conclusões: os dados observados sugerem que o estilo roque está relacionado com maior utilização de tensão na voz e que essa tensão não necessariamente impõe uma impressão negativa à voz, mas corresponde a um fator interpretativo comum ao estilo musical. Palavras-Chave: Voz; Música; Qualidade da Voz. 


\section{Introduction}

Rock music was born around nineteen fifty in USA in a society affected by the end of Second World War. The basic music style of rock was Blues and Western $\left({ }^{1}\right)$.

At that time the environment was hostile and rock music represented an alternative to protest. So rock music had the ideal of protesting, indignation and rebellion.

In this perspective, rock singers needed to show this context in their voices witch provides vocal exigencies followed by tensions and laryngeal constrictions. This is the reason of the concept that rock singers voice has normally deviations, with strain, hoarseness, and constrict (2).

To analyze the singing voice it's necessary some especial attention. It's crucial to comprehend specifically vocal demands, adversary conditions, music style and vocal alterations. Each musical style has their own characteristics and it's important to consider the differences. Many studies have been made in singing voice but most of them are based on classical singers, who have specific training, and don't represent the majority of singers. Popular musical styles require more studies to understand their vocal demands (3-4).

The goal of our research was to analyse overall degree (OD) and strain degree (SD) of Brazilian rock singers by comparing results of three different song samples.

\section{Methods}

This research was approved by the Ethical Committee and was performed with the participation of 26 male subjects volunteered for the recordings (age range 17 to 46 years), 9 professional singers and 17 amateurs, and with 9,37 time average performance as rock singer.

The research was conducted through a selfevaluation questionnaire and a perceptive-auditive analyses of songs samples. And a pilot project with 5 rock singers was used to define the procedures.

The start of this research was a self-evaluation questionnaire with sixteen objective and subjective questions about their musical education, singing style, voice care, voice perception and vocal complaints.

All voice samples were directly recorded in the computer (HP NX9020), a cappella, using a mono microphone (Plantronics headset DSP 100), laterally positioned at $10 \mathrm{~cm}$ distance, in a silent room. The instruction given was to sing as similar as on stage three different song samples: the same part of Brazilian National Anthem (BNA), the chorus of (I can't get no) Satisfaction from Rolling Stones, and a part of a self selected song (SSS) of the singers' repertoire.

BNA was selected because of its popularity in Brazil and also by not having the same characteristics of rock music.

Satisfaction was selected beyond a internet research with 250 people, contacted by email, who have appointed three songs that represent rock style. 235 different songs were chosen and the most voted was Satisfaction with 23,2\%.

The SSS was elected because it represents a comfort level in singing, because the singer has had time to get acquainted and make the adjustments demanded.

The samples were present for analyses unsystematic and $10 \%$ of them were repeated to verify the reliability intra-subject. BNA and Satisfaction during 6 seconds and SSS duration 10 seconds.

Samples were edited and evaluated by 5 Speech Language Pathologist (SLP), using a linear visual scale of 100 points ( $0=$ absence of deviation and $100=$ maximum deviation). Each SLP listened each voice sample twice.

The data were submitted for statistical analyses. The Cronbach test and the Pearson correlation test concluded that the judges have internal consistent and trustworthiness presenting high levels of agreement and reproducibility (0,651 e 0,952). Others statistical tests were used as Analyses of Spearman correlation, Mann-Whitney test, Wilcoxon test and Friedman test.

\section{Results}

The results of the self-evaluation questionnaire show that $50 \%$ of the sample refers some vocal complain, the majority (30\%) refer hoarseness as their vocal complain, others complains were vocal extension limited $(15,4 \%)$ and problems in change registers $(7,7 \%)$.

Many singers $(81,4 \%)$ describe their own voice in positives characteristics, 53,8\% have some kind of vocal care and $76,9 \%$ at some point warm up their voices, but just 34,6\% cool down their voices.

Most of them (69,2\%) sing more than one kind of rock, for example pop rock $(19,3 \%)$ heavy metal $(17,0 \%)$ and classic rock $(15,9 \%)$.

Regarding voice perception after concerts and rehearsal, 57,7\% complain of voice worsening, being 
hoarseness the most commom complain. The singers (42,3\%) believe that singing rock is a bigger challenge that singing another musical style.

In the correlation of perceptual analysis results and vocal complains (table 1), overall degree was related with vocal complains in $\operatorname{BNA}(p=0,025)$.

None statistical relation was found between time of singing rock and overall degree and strain degree in all samples.

Relating each musical sample and the two parameters analyzed (table 2), just rock samples present statistical differences in OD and SD values, being SD bigger than OD values.
In Table 3 are the results of the analyses of each parameter separated in the three different samples. OD didn't present statistical differences for the three songs, although there is a growing trend in rock direction $(\mathrm{p}=0,098)$.

SD presents significant statistical difference between the songs ( $p=0,010)$. In separated analyses, SD has statistical difference values in non-rock and rock songs ( satisfaction $\mathrm{p}=0,008$ and SSS $\mathrm{p}=0,001$ ).

The result also pointed for directed proportional relation between the parameters and two songs samples, in $\mathrm{BNA}(\mathrm{p}<0,001)$ and SSS $(\mathrm{p}=0,010)$.

TABLE 1. Relation between vocal complain and overall degree (OD) and strain degree (SD) values.

\begin{tabular}{lccc}
\hline & Media & Standard deviation & $\mathrm{p}$ \\
\hline Stretch A & & & \\
Overall Degree & 24,0 & 1,83 & 0,388 \\
Strain Degree & 26,6 & 1,85 & \\
& & & \\
Stretch B & 32,8 & 1,95 & $0,024^{*}$ \\
Overall Degree & 45,8 & 2,94 & \\
Strain Degree & & & $0,010^{*}$ \\
& & & \\
Stretch C & 38,4 & 2,70 & \\
Overall Degree & 55,8 & 3,17 & \\
Strain Degree &
\end{tabular}

Stretch A (BNA), Stretch B ( Satisfaction) e Stretch C (SSS).

TABLE 2. Relation between overall degree (OD) and strain degree (SD) for each song.

\begin{tabular}{|c|c|c|c|c|c|c|}
\hline \multirow{2}{*}{ Aspects } & \multicolumn{2}{|c|}{ Stretch A } & \multicolumn{2}{|c|}{ Stretch B } & \multicolumn{2}{|c|}{ Stretch C } \\
\hline & Media & $\mathrm{p}$ & Media & $\mathrm{p}$ & Media & $\mathrm{p}$ \\
\hline \multicolumn{7}{|l|}{ Overall Degree } \\
\hline Without complain & 29,0 & \multirow{2}{*}{$0,025^{*}$} & 33,0 & \multirow{2}{*}{0,898} & 35,1 & \multirow{2}{*}{0,41} \\
\hline With complain & 18,1 & & 32,5 & & 42,3 & \\
\hline \multicolumn{7}{|l|}{ Strain Degree } \\
\hline Without complain & 30,6 & \multirow{2}{*}{0,35} & 49,2 & \multirow{2}{*}{0,537} & 59,8 & \multirow{2}{*}{0,643} \\
\hline With complain & 21,9 & & 41,8 & & 51,1 & \\
\hline
\end{tabular}

Stretch A (BNA), Stretch B (Satisfaction) e Stretch C (SSS)

TABLE 3. Relation of overall degree (OD) in the three songs and relation of strain degree (SD) values in the three songs.

\begin{tabular}{llll}
\hline & Media & Standard Deviation & $\mathrm{p}$ \\
\hline Overall Degree A & 24,0 & 1,83 & \\
Overall Degree B & 32,8 & 1,95 & 0,098 \\
Overall Degree C & 38,4 & 2,70 & \\
& & & \\
Strain Degree A & 26,6 & 1,85 & $0,010^{*}$ \\
Strain Degree B & 45,8 & 2,94 & \\
Strain Degree C & 55,8 & 3,17 &
\end{tabular}

Stretch A (BNA), Stretch B ( Satisfaction) e Stretch C (SSS); Correlation: Stretch A: OD X SD: Coef*=0,666 p<0,001; Stretch B: OD X SD: Coef=0,335 p=0,094; Stretch C: OD X SD: Coef=0,497 p=0,010; SDA X SDB: p=0,008; SDA X SDC: p=0,001; SDB X SDC: $\mathrm{p}=0,258 ;{ }^{*}$ Coef $=$ corelation coeficiente. 


\section{Discussão}

Rock music is a style that transformed the way of sing, of instrumentation and composition. For many singers this resulted in voice with deviations. Because of that was created the idea that rock singers have high strains levels in their voices.

In this research, $50 \%$ of the singers refer some vocal complains, but all of them refer just one kind of complain. Hoarseness was referred by $30,8 \%$ of the singers, this value is close to what was found in a research of any vocal problems in general population (29,9\%). The fact of singers just pointed one vocal complain is coherent with general population data (1,7attual symptoms and 2,3 past symptoms) (5-6).

The most of the complaints, excepting hoarseness, refer to specific difficult in singing technic, which does not indicate necessary vocal problems.

This research also find that $53,8 \%$ has some kind of vocal care, this demystify the concept that rock singers are negligent with their voices, 76,9\% warm up their voice at some times and just 34,6\% cool down their voice. This is a high number comparing to previous studies made in Brazil with all kinds of voice professionals, which shows a change of attitude. Although it is important to know that this change isn't complete yet, since just 34,6\% of the sample cool down their voice at some moment (7-8).

Most of them (69,2\%) sing more than one kind of rock, witch imply different vocal demands during concerts, specially heavy metal and hard rock, styles with high demands.

Singing more than one rock style and the need of making different vocal adjustments can be related to the fact that $42,3 \%$ consider rock more challenger than others music styles.

About of perceptual analysis the table 1 shows that just OD in non rock sample has relation with vocal complains $(p=0,025)$. In singers with no complains the medium value of OD was bigger $(29,0$ e 18,1), witch alloyed the conclusion that vocal complains are not related with overall voice degree.

In table 2 it's visible that just rock samples have different medium values of OD e SD (satisfaction $\mathrm{p}=0,024$ and SSS $\mathrm{p}=0,010$ ). Values of SD were bigger than OD values. It means that strain wouldn't be the only parameter to qualify a voice as deviated.

The table 3 shows that despite the absolute increment on the values of overall degree from Brazilian National Anthem to Satisfaction to Selfselected song, the values didn't have significant modification.
In table 3 , SD presents significant statistical difference between the samples $(\mathrm{p}=0,010)$. Looking at all samples separated, the values of Anthem strain degree were statistically different from the strain degree of rock samples. Singing rock implies significant raise of strain in voice, concluding that strain in the voice is one of the characteristics of rock style.

The results show clear difference between all song samples, existing similarity in rock songs.

The relation between two parameters in two samples was directly proportional, in Anthem $(\mathrm{p}<0,001)$ and in SSS $(\mathrm{p}=0,010)$, showing that bigger strain degree means bigger overall degree, and this relation isn't just for rock style.

Despite the relation between SD and OD, isn't just the strain degree that gives an impression of deviation in a voice. The parameters were flexible and suffered modifications for each song samples, that indicates that music style interferes in qualify vocal deviation.

Analyzing the parameters OD and SD and comparing this analyses with the standards for perceptual analyses in visual scale of $100 \mathrm{~cm}$ the conclusion is that in Anthem OD and SD had normal values (below 35,5), Satisfaction had OD normal and SD in low/moderate deviation (between 35,6 and $50,5)$ and SSS had OD in low/moderate and SD moderate/intense (between 50,6 and 90,5) (9).

The biggest strain values were found in rock songs, being SSS the samples with bigger values in both parameters. That probably happened because the singers had shown more comfort to interpret the self-selected song, getting closer to their sing reality. Satisfaction, despite being a classical rock song, wasn't part of their repertoire. Was clear that the two rock songs samples have close values of OD and SD and this values was different the what was found in Anthem.

The blues, rock basic style, is close to a strain vocal style, strain that was also found is this research. Presenting vocal strain and laryngeal constriction can justify low frequency of vibrato in rock singers than in singers from others styles (1011).

The vocal strain isn't characteristic of the singer but the style that he sings. The SD found $(58,5)$ isn't a extreme value, witch can be justify by the fact that recordings were a cappella and outside concerts environment.

Rock singers can present extreme muscles strain, but this means high levels of laryngeal work and not pathology. Muscle strain do not seems to be 
affected by vocal technic and samples of strain singing voice can present normal laryngoscope, as was seeing in studies of middle eastern singing style (style considered vocally with high strain). Other sing studies about music styles that presents strain in singing voice as Mongolian Throat singing and Enka found sign of interpretative vocal strain, but without statistical significance (12-13-14-15-16).

The concept of normal voice isn't well defined, suffering many kind of influence as style, sex and musical taste.

\section{References}

1. Tinti SPM. O Roque independente no Brasil, segundo a mídia especializada - um estudo de caso da Revista Outracoisa. [monografia]. São Paulo(SP): Pontifica Universidade Católica de São Paulo; 2005.

2. Behlau M, Feijó D, Madazio G, Rehder MI, Azevedo R, Ferreira AE. Voz profissional: aspectos gerais e atuação fonoaudiológica. In: Voz - o livro do especialista. Vol II. Rio de Janeiro: Revinter; 2005. p. 287-372.

3. Stone R, Cleveland T, Sundberg J, Prokop J. Aerodynamic and acoustical measures of speech, operatic, and broadway vocal styles in a professional female singer. J Voice. 2003; 17(3):283-97.

4. Sundberg J, Cleveland T, Stone R, Iwarsson J. Voice source characteristics in six premier country singers. J Voice. 1999; 13(2):168-83.

5. Roy N, Merrill RM, Gray SD, Smith EM. Voice disorders in the general population: prevalence, risk factors, and occupational impact. Laryngoscope. 2005; 115: 1988-95.

6. Behlau M, Zambon F, Guerrieri AC, Roy N, GVP. Panorama epidemiológico sobre a voz do professor no Brasil; Anais do $17^{\circ}$ Congresso Brasileiro de Fonoaudiologia e $1^{\circ}$ Congresso Ibero-Americano de Fonoaudiologia, 2009, Salvador(BA).

7. Oliveira LVDA, Behlau M. Perfil vocal de cantores amadores de banda de roque. [monografia]. São Paulo(SP): Centro de Estudos da Voz; 2004.

8. Duprat AC, Eckley C, Silva MAA, Costa HO. Avaliação laringológica de cantores da noite. In: Tópicos em fonoaudiologia, Vol III. São Paulo: Lovise; 1996. p. 35560 .
Strain is part of style's interpretation, but shouldn't damage singer's career. The challenge is to help the singer to use the necessary strain without producing vocal deviation.

\section{Conclusion}

Rock is a musical style that has high vocal demands and rock singers modify their voices according to the song using strain as an interpretative resource, particularly associated to rock.

9. Yamazaki R, Leão SHS, Madazio G, Padovani M, Azevedo R, Behlau M. Correspondência entre escala analógico-visual e a escala numérica na avaliação perceptivo-auditiva das vozes. XVI Congresso Brasileiro de Fonoaudiologia, 2008, Campos do Jordão(SP).

10. Thalén M, Sundberg J. Describing different styles of singing - a comparison of a female singer's voice source in "Classical", "Pop", "Jazz" and "Blues". Log Phon Vocol. 2001; 26: 82-93.

11. Curcio D, Behlau M. Medidas de variação da frequência do vibrato em três estilos de canto profissional. [monografia]. São Paulo(SP): Centro de Estudos da Voz; 1999.

12. Koufman J. et al. Laryngeal Biomechanics of the singing voice. Otolaringol Head Neck Surg(SP). 1996;115:527-37.

13. Hamdan AL, Sibai A, Moukarbel RV, Deeb R. Laryngeal biomechanics in middle eastern singing. J Voice. 2006;20(4): 579-84.

14. Hamdan AL, Deeb R, Tohme RA, Rifai H, Husseini S, Fuleihan N. Vocal technique in a group of Middle Eastern singers. Folia Phoniatr Logop. 2008;60:217-21.

15. Lindestad P, Södersten M, Merker B, Granqvist S. Voice source characteristics in mongolian "throat singing" studied with high-speed imaging technique, acoustic spectra, and inverse filtering. J Voice. 2001;15(1):78-85.

16. Nakao EMH, Behlau M. Configuração laríngea durante o canto japonês em estilo Enka. [monografia]. São Paulo(SP): Centro de Estudos da Voz; 2001. 